\title{
YIELD AND QUALITY OF WINTER COMMON VETCH (Vicia sativa L.) HAYLAGE DEPENDING ON SOWING METHOD
}

\author{
Đ. Karagić, S. Vasiljević, S. Katić, A. Mikić, D. Milić, B. Milošević, N. \\ Dušanić
}

Institute of Field and Vegetable Crops, Novi Sad, Republic of Serbia Corresponding author: djura.karagic@ifvens.ns.ac.rs

Original scientific paper

\begin{abstract}
In order to determine an optimum ratio of vetch and wheat (Triticum aestivum L.) components in their mixture, there has been carried out a four-year trial (autumn 2005 - spring 2009) aimed at the yield and quality of winter vetch haylage. The sowing rate of winter vetch was $120 \mathrm{~kg} \mathrm{ha}^{-1}$, while the sowing rate of winter wheat was $0,15,20,25$ and $30 \mathrm{~kg} \mathrm{ha}^{-1}$. An increased proportion of the cereal in its mixture with vetch significantly decreases the stand lodging, have a positive influence on forage yield, but haylage quality is of a poorer quality. Quality characteristics such as crude protein and lignin content, total digestible nutrients, dry matter intake and relative feed value were highest in monoculture common vetch followed by mixture with the lowest rate of wheat. Neutral detergent fiber content was positively affected by intercropping. There were no significant differences among treatments for acid detergent fiber content, digestible dry matter, and net energy for lactation. The most favorable balance between the haylage yield and quality, as well as the highest CP yield $\left(1482 \mathrm{~kg} \mathrm{ha}^{-1}\right)$, was achieved by the mixture of $120 \mathrm{~kg} \mathrm{ha}^{-1}$ of the vetch seed and $15 \mathrm{~kg} \mathrm{ha}^{-1}$ of wheat.
\end{abstract}

Key words: crude proteins, forage, haylage, intercropping, vetch

\section{Introduction}

Winter form of common vetch (Vicia sativa L.) is an annual legume crop rich in protein that is traditionally used in the regions of South East Europe as high quality roughage, that is, green forage or hay. Recently it is increasingly used in the form of haylage, due to numerous advantages this way of conservation offers (Seven and Cerci, 2006). Also, the enhanced quality of the conserved forage allowed a greater milk yield and a reduction in the winter feeding costs. Carefully 
managing the haylage during storage prevented the risk of clostridial or other bacterial contamination in the milk and produced cheeses (Borreani et al., 2007). However, vetch has a vine growing habit and if sown as monocrop heavily lodges. As a result, forage yield and quality start to decrease due to the decomposition of herbage (Gulcan et al., 1988; Aydin and Tosun, 1991; Karagić et al., 2008; Mihailović et al., 2007, 2008). Because of all this, it is sown with winter-sown small grains, such as oats (Avena sativa L.), wheat (Triticum aestivum L.), barley (Hordeum vulgare L.) and triticale (x Triticosecale Wittmack).

In mixtures, companion cereals provide structural support for common vetch growth, improve light interception, and facilitate mechanical harvest, whereas common vetch in mixtures improves the quality of forage (Roberts et al., 1989; Caballero et al., 1995; Lithourgidis et al., 2006). So far, there has been no consent opinion on what cereal is the best companion crop for vetch (Caballero and Goicoechea, 1986; Thompson et al., 1992). Roberts et al. (1989) reported that the most suitable cereal for mixtures with common vetch is wheat. Due to a problematic response to low temperatures in oats, in Serbia it is wheat that is most often used as a companion crop for winter vetch.

Although numerous studies have examined the effects of varying seeding ratios (Aydogdu and Acikgoz, 1995; Karadag and Buyukburc, 2003; Kokten et al., 2009; Lithourgidis et al., 2006; Tukel et al.1997; Tuna and Orak, 2007), the optimum seeding rates for those combinations are not well-defined. The conclusions these authors have drawn are highly influenced by the climatic conditions their testing had been carried out in. Common vetch produces low yields particularly in areas with low rainfall (Hadjichristodoulou, 1978) and seriously hinders harvest because of lodging in areas with high rainfall (Robinson, 1969; Caballero et al., 1995; Karagić et al., 2008).

For the prevailing agro-ecological conditions of Serbia, Mišković (1986), recommends that the sowing rates are $150 \mathrm{~kg} \mathrm{ha}^{-1}$ for common vetch and $30-35 \mathrm{~kg}$ $\mathrm{ha}^{-1}$ for cereals. However, it has been demonstrated that these sowing rates are too high for the contemporary agriculture (Karagić et al., 2008). By this reason, the objective of this study was to compare the haylage yield and quality from mixed stands of vetch and wheat obtained when several seeding rates of wheat were combined with constant seeding ratio of vetch.

\section{Materials and Methods}

A field experiment was conducted during four growing seasons $(2005 / 06$, 2006/07, 2007/08, 2008/09) at the experimental field of the Institute of Field and Vegetable Crops, Novi Sad, in northern Serbia $\left(45^{\circ} 20^{\prime} \mathrm{N}, 19^{\circ} 51^{\prime} \mathrm{E}\right)$. The area has a continental semiarid to semihumid climate, a mean annual air temperature of $11.0^{\circ} \mathrm{C}$, an annual sum of precipitation of $617 \mathrm{~mm}$, with an uneven distribution of precipitation. The experiment was established in a loamy soil with $\mathrm{pH} 7.2$, and 
organic matter content $2.82 \%, \mathrm{~N}^{-N} \mathrm{O}_{3} 17.2 \mathrm{ppm}, \mathrm{P}_{2} \mathrm{O}_{5} 20.7 \mathrm{ppm}$ and $\mathrm{K}_{2} \mathrm{O} 29.1$ ppm (0 to $30 \mathrm{~cm}$ depth). Nitrogen and $\mathrm{P}_{2} \mathrm{O}_{5}$ at 15 and $78 \mathrm{~kg} \mathrm{ha}^{-1}$, respectively, were incorporated as monoammonium phosphate (10-52-0) into the soil before ploughing. The previous crop was oilseed rape, with harvest residues chopped and incorporated into the soil.

The experimental design was a randomized complete block with five treatments (vetch monoculture and four mixtures of common vetch with wheat) replicated four times. The sowing rate of vetch in all treatments was $120 \mathrm{~kg} \mathrm{ha}^{-1}$, while the sowing rates of wheat were $0 \mathrm{~kg} \mathrm{ha}^{-1}\left(\mathrm{SRW}_{0}\right), 15 \mathrm{~kg} \mathrm{ha}^{-1}\left(\mathrm{SRW}_{15}\right), 20 \mathrm{~kg}$ $\mathrm{ha}^{-1}\left(\mathrm{SRW}_{20}\right), 25 \mathrm{~kg} \mathrm{ha}^{-1}\left(\mathrm{SRW}_{25}\right)$ and $30 \mathrm{~kg} \mathrm{ha}^{-1}\left(\mathrm{SRW}_{30}\right)$. The plot size was $60 \mathrm{~m}^{2}$ $(5 \times 12 \mathrm{~m})$ and the treatments were separated by a $2 \mathrm{~m}$ buffer zone.

The seeds of vetch and wheat were mixed before the sowing that was done in the first decade of October in all four years, with $12.5 \mathrm{~cm}$ between rows. Mean seed weights were $50.2 \mathrm{~g}$ and $39.8 \mathrm{~g}$ per 1000 seeds for common vetch and wheat, respectively. There were applied usual modern agronomic practices of a vetch production. The cutting and chopping of the forage were done by hand with a scythe in the stage of first pods forming and on the area of $10 \mathrm{~m}^{2}$ in the middle of each plot. The samples of $1 \mathrm{~kg}$ biomass from each plot were dried at $65^{\circ} \mathrm{C}$ for $72 \mathrm{~h}$ in order to determine the dry matter content.

The cut and dried biomass was placed in a silotrench without inoculants. After 60 days of fermenting, the haylage samples of $400 \mathrm{~g}$ each were taken, with an analysis of the basic quality parameters. Total $\mathrm{N}$ was determined using the Kjeldahl method and crude protein $(\mathrm{CP})$ was calculated by multiplying the $\mathrm{N}$ content by 6.25 (AOAC, 1980). Neutral and acid detergent fiber (NDF and ADF) and acid detergent lignin (ADL) were determined using the procedure by Goering and van Soest (1970). Total digestible nutrients (TDN), digestible dry matter (DDM), dry matter intake (DMI), relative feed value (RFV) and net energy for lactation $\left(\mathrm{NE}_{\mathrm{L}}\right)$ were estimated according to the following equations:

$$
\begin{aligned}
& \text { TDN }=73.5+0.62(\% \mathrm{CP})-0.71(\% \mathrm{ADF}) \\
& \mathrm{DDM}(\%)=88.9-(\% \mathrm{ADF} \times 0.779) \\
& \mathrm{DMI}(\% \mathrm{DM})=120: \% \mathrm{NDF} \\
& \mathrm{RFV}=(\% \mathrm{DDM} \times \% \mathrm{DMI}): 1.29 \\
& \mathrm{NE}_{\mathrm{L}}=(1.044-(0.0119 \times \% \mathrm{ADF})) \times 2.205
\end{aligned}
$$

The results were processed by the analysis of variance (ANOVA). The treatment mean differences were separated by the least significant difference (LSD) test at the 0.05 probability level. For the entire statistical analysis the MSTAT-C software was used (MSTAT-C, 1988). Because the analyses of variance for haylage yield and quality indicated no treatment $\mathrm{x}$ experimental time interaction, the values are reported as means of the four growing seasons. 


\section{Results and Discussion}

The increase of the cereal in its mixture with vetch significantly increased the yields of both haylage and DM (Table 1), what agrees with the results by Roberts et al. (1989). The highest vetch haylage yield (18938 kg ha-1) was achieved in the treatment with the highest wheat sowing rate. By decreasing the wheat sowing rate, the haylage yield was also decreasing, that is, from $9.4 \%$ in $\mathrm{SRW}_{25}$ to $35.4 \%$ in the vetch monocrop. There were no significant differences in the vetch haylage yield between the treatments $\mathrm{SRW}_{15}$ and $\mathrm{SRW}_{20}$. An identical trend, to that of haylage yield was observed for the dry matter yield (Table 1). The influence of the wheat sowing rate on the vetch proportion in the total yield was significant for all treatments (Table 1).

Table 1. Haylage yield, dry matter yield and vetch contribution of monoculture and mixtures of common vetch with wheat

\begin{tabular}{|l|c|c|c|}
\hline Treatment & $\begin{array}{c}\text { Haylage yield } \\
\left(\mathrm{kg} \mathrm{ha}^{-1}\right)\end{array}$ & $\begin{array}{c}\text { Dry matter yield } \\
\left(\mathrm{kg} \mathrm{ha}^{-1}\right)\end{array}$ & $\begin{array}{c}\text { Vetch proportion in } \\
\text { the total yield (\%) }\end{array}$ \\
\hline $\mathrm{SRW}_{0}$ & $12240 \mathrm{~d}^{*}$ & $5430 \mathrm{~d}$ & $100.00 \mathrm{a}$ \\
\hline $\mathrm{SRW}_{15}$ & $14970 \mathrm{c}$ & $6641 \mathrm{c}$ & $80.66 \mathrm{~b}$ \\
\hline $\mathrm{SRW}_{20}$ & $15366 \mathrm{c}$ & $6816 \mathrm{c}$ & $74.27 \mathrm{c}$ \\
\hline $\mathrm{SRW}_{25}$ & $17151 \mathrm{~b}$ & $7718 \mathrm{~b}$ & $62.91 \mathrm{~d}$ \\
\hline SRW $_{30}$ & $18938 \mathrm{a}$ & $8400 \mathrm{a}$ & $56.12 \mathrm{e}$ \\
\hline Average & 15733 & 7001 & 74.79 \\
\hline LSD 0.05 & 1378 & 623 & 3.73 \\
\hline
\end{tabular}

*Values within the columns followed by the same letter do not differ significantly at the 0.05 level of probability according to LSD test

The highest CP content was in the vetch monocrop $\left(251.8 \mathrm{~g} \mathrm{~kg}^{-1} \mathrm{DM}\right)$ and with the lowest wheat sowing rate (223.1 $\left.\mathrm{g} \mathrm{kg}^{-1} \mathrm{DM}\right)$, with no significant differences between these two treatments (Table 2). In all mixtures, the CP content decreased as cereal proportion increased, what responds to the results of numerous authors (Roberts et al., 1989; Caballero et al., 1995; Balabanli and Turk, 2006; Lithourgidis et al., 2006). The decrease of the CP content varied from $30.8 \%$ with $\mathrm{SRW}_{20}$ to $59.0 \%$ with $\mathrm{SRW}_{30}$. The highest CP yield was achieved with $\mathrm{SRW}_{15}$ $\left(1482 \mathrm{~kg} \mathrm{ha}^{-1}\right)$. Unlike our results, Tuna and Orak (2007) recommend the mixture of $25 \%$ vetch and $75 \%$ of oat, on the basis of solely DM yield $\left(6.5 \mathrm{t} \mathrm{ha}^{-1}\right)$.

The highest NDF content (564.7 $\left.\mathrm{g} \mathrm{kg}^{-1} \mathrm{DM}\right)$ was in the treatment with the highest wheat sowing rate (Table 2). The decrease of the wheat sowing rate caused the decrease of NDF content, from $7.7 \%$ with $\mathrm{SRW}_{25}$ to $25.4 \%$ in the vetch monocrop. The lowest NDF concentration was in vetch monocrop and the increase of the wheat sowing rate caused the increase of NDF content, which is in agreement with most other studies (Caballero et al., 1995; Castro et al., 2000; Assefa and Ledin, 2001). Having tested the wheat monocrop silage quality, Siefers 
and Bolsen (1997) determined a relatively low forage quality as evidenced by high NDF and ADF percentages (higher than 60\% NDF and 40\% ADF contents).

The average ADF content in the vetch haylage was $359.5 \mathrm{~g} \mathrm{~kg}^{-1} \mathrm{DM}$, with no significant differences between the treatments (Table 2). The actual values for ADF found in this study and the lack of significant differences agree with other studies (Caballero et al., 1995; Castro et al., 2000; Lithourgidis et al., 2006).

The lignin content was highest in the vetch monocrop (98.9 $\left.\mathrm{g} \mathrm{kg}^{-1} \mathrm{DM}\right)$. The increase of the wheat sowing rate from $20 \mathrm{~kg} \mathrm{ha}^{-1}$ on caused a significant decrease in the lignin content, from $9.2 \%$ to $37.6 \%$ (Table 2). The results obtained respond to these from other studies (Caballero et al., 1995, 2001; Rebole et al., 2004; Lithourgidis et al., 2006).

Table 2. Crude protein (CP) content and crude protein yield, neutral (NDF) and acid detergent fiber (ADF) and acid detergent lignin (ADL) in haylage of monoculture and mixtures of common vetch with wheat

\begin{tabular}{|l|c|c|c|c|c|}
\hline Treatment & $\begin{array}{c}\mathrm{CP} \\
\left(\mathrm{g} \mathrm{kg}^{-1} \mathrm{DM}\right)\end{array}$ & $\begin{array}{c}\mathrm{CP} \\
\left(\mathrm{kg} \mathrm{ha}^{-1}\right)\end{array}$ & $\begin{array}{c}\mathrm{NDF} \\
\left(\mathrm{g} \mathrm{kg}^{-1} \mathrm{DM}\right)\end{array}$ & $\begin{array}{c}\mathrm{ADF} \\
\left(\mathrm{g} \mathrm{kg}^{-1} \mathrm{DM}\right)\end{array}$ & $\begin{array}{c}\mathrm{ADL} \\
\left(\mathrm{g} \mathrm{kg}^{-1} \mathrm{DM}\right)\end{array}$ \\
\hline $\mathrm{SRW}_{0}$ & $251.8 \mathrm{a}$ & $1367 \mathrm{~b}$ & $421.2 \mathrm{~d}$ & $356.3 \mathrm{a}$ & $98.9 \mathrm{a}$ \\
\hline $\mathrm{SRW}_{15}$ & $223.1 \mathrm{a}$ & $1482 \mathrm{a}$ & $448.4 \mathrm{~cd}$ & $362.0 \mathrm{a}$ & $93.3 \mathrm{ab}$ \\
\hline $\mathrm{SRW}_{20}$ & $174.3 \mathrm{~b}$ & $1188 \mathrm{c}$ & $466.9 \mathrm{c}$ & $371.9 \mathrm{a}$ & $89.2 \mathrm{~b}$ \\
\hline $\mathrm{SRW}_{25}$ & $123.4 \mathrm{c}$ & $952 \mathrm{~d}$ & $521.3 \mathrm{~b}$ & $355.4 \mathrm{a}$ & $64.6 \mathrm{c}$ \\
\hline $\mathrm{SRW}_{30}$ & $103.2 \mathrm{~d}$ & $867 \mathrm{e}$ & $564.7 \mathrm{a}$ & $352.1 \mathrm{a}$ & $61.7 \mathrm{c}$ \\
\hline Average & 175.2 & 1171 & 484.5 & 359.5 & 81.5 \\
\hline LSD 0.05 & 13.8 & 69 & 37.5 & 25.6 & 9.3 \\
\hline
\end{tabular}

*Values within columns followed by the same letter do not differ significantly at the 0.05 level of probability according to LSD test

The highest TDN was determined in the vetch monocrop (Table 3). There were no significant differences in the TDN content between the treatments $\mathrm{SRW}_{0}$ and $\mathrm{SRW}_{15}$. The increase of the wheat sowing rate above $15 \mathrm{~kg} \mathrm{ha}^{-1}$ caused a significant decrease of the TDN content in haylage, from $9.3 \%$ to $14.0 \%$, in comparison with $\mathrm{SRW}_{0}$. Similar values and trends were reported by others where legumes included in the intercropping system significantly increased the TDN (Osman and Nersoyan, 1986; Roberts et al., 1989). However, Lithourgidis et al. (2006) found that triticale and oat monocultures had higher TDN than monoculture common vetch, and TDN decreased as the common vetch seeding proportion increased in mixtures. The differences in this research are a consequence of various methods used to determine TDN. The average DDM was $608.9 \mathrm{~g} \mathrm{~kg}^{-1} \mathrm{DM}$, with no significant differences between the treatments (Table 3 ). 
Table 3. Total digestible nutrients (TDN), digestible dry matter (DDM), dry matter intake (DMI), relative feed value (RFV) and net energy for lactation $\left(\mathrm{NE}_{\mathrm{L}}\right)$ of the haylage of monoculture and mixtures of common vetch with wheat

\begin{tabular}{|l|l|l|c|l|c|}
\hline Treatment & $\begin{array}{c}\mathrm{TDN} \\
\left(\mathrm{g} \mathrm{kg}^{-1} \mathrm{DM}\right)\end{array}$ & $\begin{array}{c}\text { DDM } \\
\left(\mathrm{g} \mathrm{kg}^{-1} \mathrm{DM}\right)\end{array}$ & $\begin{array}{c}\text { DMI } \\
\left(\mathrm{g} \mathrm{kg}^{-1} \text { of }\right. \\
\text { body weight })\end{array}$ & $\begin{array}{c}\mathrm{RFV} \\
(\%)\end{array}$ & $\begin{array}{c}\mathrm{NE}_{\mathrm{L}} \\
\left(\mathrm{Mcal} \mathrm{kg}^{-1}\right)\end{array}$ \\
\hline $\mathrm{SRW}_{0}$ & $638.1 \mathrm{a}$ & $611.4 \mathrm{a}$ & $28.5 \mathrm{a}$ & $135.04 \mathrm{a}$ & $1.367 \mathrm{a}$ \\
\hline $\mathrm{SRW}_{15}$ & $616.3 \mathrm{ab}$ & $607.0 \mathrm{a}$ & $26.8 \mathrm{ab}$ & $126.07 \mathrm{ab}$ & $1.352 \mathrm{a}$ \\
\hline $\mathrm{SRW}_{20}$ & $579.0 \mathrm{bc}$ & $599.3 \mathrm{a}$ & $25.7 \mathrm{~b}$ & $119.37 \mathrm{~b}$ & $1.326 \mathrm{a}$ \\
\hline $\mathrm{SRW}_{25}$ & $559.2 \mathrm{c}$ & $612.1 \mathrm{a}$ & $23.0 \mathrm{c}$ & $109.11 \mathrm{c}$ & $1.369 \mathrm{a}$ \\
\hline $\mathrm{SRW}_{30}$ & $549.0 \mathrm{c}$ & $614.7 \mathrm{a}$ & $21.3 \mathrm{c}$ & $101.47 \mathrm{c}$ & $1.378 \mathrm{a}$ \\
\hline Average & 588.3 & 608.9 & 25.0 & 118.21 & 1.359 \\
\hline LSD 0.05 & 43.7 & 38.6 & 1.7 & 9.31 & 0.114 \\
\hline
\end{tabular}

*Values within columns followed by the same letter do not differ significantly at the 0.05 level of probability according to LSD test

The highest DMI was in the vetch monocrop and the lowest wheat sowing rate, 28.5 and $26.8 \mathrm{~g} \mathrm{~kg}^{-1}$ of $\mathrm{BW}$, respectively. In comparison to the vetch monocrop, the values of the other treatments were significantly lower, from 9.8 to $25.3 \%$ (Table 3 ). The highest RFV was determined in the vetch monocrop and the lowest wheat sowing rate, 135.04 and $126.07 \%$, respectively, which is consistent with results of Hackman et al. (2008). According to Dunham (1998) the best use of $\mathrm{RFV}$ is for selecting forages to be used in rations which require high nutrient density such as high producing dairy cows. Alfalfa with a RFV less than 140 should not be considered good enough for early lactation cows. However, alfalfa with a RFV of 125 to 140 could be fed to dairy cows in late lactation. Lower RFV alfalfa would be adequate for growing heifers.

The average $\mathrm{NE}_{\mathrm{L}}$ was $1.359 \mathrm{Mcal} \mathrm{kg}^{-1}$, with no significant differences between the treatments (Table 3). The different content of common vetch did not affect DDM and $\mathrm{NE}_{\mathrm{L}}$ as there were no significant differences among treatments, which is in agreement with results of Lithourgidis et al. (2006).

\section{Conclusion}

For forage crops it is important to produce greater forage yields per hectare, higher nutritional quality (percentage composition of selected nutrients) or combined nutrient yields. On the basis of the results obtained by this research, it can be concluded that the most favorable balance between haylage yield and quality, as well as the highest CP yield $\left(1,482 \mathrm{~kg} \mathrm{ha}^{-1}\right)$, was achieved by sowing the mixture of $120 \mathrm{~kg} \mathrm{ha}^{-1}$ of vetch and $15 \mathrm{~kg} \mathrm{ha}^{-1}$ of wheat, thus recommending this combination to the farmers for the agro-ecological conditions of South East Europe. 


\title{
Acknowledgment
}

This research was subsidized by Ministry of Education and Science of the Republic of Serbia (Project No. TR 31024).

\section{Prinos i kvalitet senaže ozime grahorice (Vicia sativa L.) u zavisnosti od načina setve}

\author{
Đ. Karagić, S. Vasiljević, S. Katić, A. Mikić, D. Milić, B. Milošević, N. Dušanić
}

\section{Rezime}

Ozima grahorica (Vicia sativa L.) vrlo je osetljiva na poleganje i zbog toga se seje u smeši sa strnim žitima koja služe kao potporni usev. Povećanjem učešća strnine u smeši sa grahoricom značajno se smanjuje poleganje useva, pozitivno se utiče na prinos krme ali je proizvedena senaža slabijeg kvaliteta. U cilju utvrđivanja optimalnog odnosa strnine i grahorice u travno-leguminoznoj smeši izvršena su četvorogodišnja (2006-2009.) ispitivanja prinosa i kvaliteta senaže ozime grahorice. Setvena norma grahorice iznosila je $120 \mathrm{~kg} \mathrm{ha}^{-1}$, a pšenice 0,15 , 20,25 i $30 \mathrm{~kg} \mathrm{ha}^{-1}$. Oged je postavljen po randomiziranom blok sistemu u četiri ponavljanja, površina osnovne parcelice iznosila je $60 \mathrm{~m}^{2}$. Kosidba useva obavljena je u fazi formiranja mahuna. Pokošena masa sušena je na parceli do sadržaja vlage od 55\%. Pokošena i prosušena masa smeštena je u silotrenč bez dodatka inokulanta. Nakon 45 dana fermentacije uzeti su uzorci senaže od po $400 \mathrm{~g}$. Obavljena je standardna analiza osnovnih pokazatelja kvaliteta (sadržaj sirovih proteina, sirovih masti, sirove celuloze, pepela i BEM) i analiza po Van Soest-u (NDF, ADF i lignin). Prosečan prinos senaže iznosio je $15733 \mathrm{~kg} \mathrm{ha}^{-1}$. Najmanji prinos ostvaren je na tretmanu bez pšenice, $12240 \mathrm{~kg} \mathrm{ha}^{-1}$, a najveći na tretmanu sa $30 \mathrm{~kg} \mathrm{ha}^{-1}$ pšenice, $18938 \mathrm{~kg} \mathrm{ha}^{-1}$. Nisu utvrđene signifikantne razlike u prinosu senaže na tretmanima sa 15 i $20 \mathrm{~kg} \mathrm{ha}^{-1}$ pšenice $\left(14970\right.$ i $\left.15366 \mathrm{~kg} \mathrm{ha}^{-1}\right)$. Prosečan sadržaj sirovih proteina iznosio je $21,44 \%$, najveći je bio na tretmanu bez pšenice $25,18 \%$, a najmanji na tretmanu sa $30 \mathrm{~kg} \mathrm{ha}^{-1}$ pšenice $15,82 \%$. Povećanjem učešća strnine u smeši sa grahoricom značajno se smanjuje poleganje useva, pozitivno se utiče na prinos krme ali je proizvedena senaža slabijeg kvaliteta. Pokazatelji kvaliteta kao što su sadržaj NDF, ukupno svarljivih nutrijenata (TDN), konzumiranje suve materije senaže (DMI) i relativna hranljiva vrednost (RFV) bili su najveći u čistom usevu grahorice, kao i na tretmanu sa najmanjom setvenom normom pšenice. Nisu utvrđene statistički značajne razlike između tretmana za sadržaj ADF, svarljivost suve materije (DDM) i $\mathrm{NE}_{\mathrm{L}}$. Najpovoljniji odnos između prinosa i kvaliteta senaže, te najveći prinos sirovih proteina $\left(1482 \mathrm{~kg} \mathrm{ha}^{-1}\right)$ ostvaren 
je mešavinom $120 \mathrm{~kg} \mathrm{ha}^{-1}$ semena grahorice i $15 \mathrm{~kg} \mathrm{ha}^{-1}$ semena pšenice, stoga ova kombinacija može da se preporuči proizvođačima za agroekološke uslove jugoistočne Evrope.

\section{References}

ASSOCIATION OF OFFICIAL ANALYTICAL CHEMISTS (AOAC) (1980): Official Methods of Analysis. 11th ed. AOAC, Washington, DC, $125 \mathrm{p}$.

ASSEFA G., LEDIN I. (2001): Effect of variety, soil type and fertilizer on the establishment, growth, forage yield, quality and voluntary intake by cattle of oats and vetches cultivated in pure stands and mixtures. Anim. Feed Sci. Technol., 92, 95-111.

AYDIN I., TOSUN F. (1991): The effect of the ratios of common vetch and cereals in the mixtures upon the yields of hay and crude protein and crude protein ratio under the ecological conditions of Samsun-Turkey. 2nd National Congress of Grassland and Forage Crops in Turkey, 28-31 May 1991, Izmir, 332-341.

AYDOGDU L., ACIKGOZ E. (1995): Effect of seeding rate on seed and hay yield in common vetch (Vicia sativa L.). J. Agron. and Crop Sci., 174, 181-187.

BALABANLI C., TURK M. (2006): The effects of different harvesting periods in some forage crops mixture on herbage yield and quality. Journal of Biological Sciences, 6, 2, 265-268.

BORREANI G., GIACCONE D., MIMOSI A., TABACCO E. (2007): Comparison of hay and haylage from permanent Alpine meadows in winter dairy cow diets. J. Dairy Sci., 90, 5643-5650.

CABALLERO R., GOICOECHEA E.L. (1986): Utilization of winter cereals as companion crops for common vetch and hairy vetch. Proceedings of the 11th General Meeting of the European Grassland Federation, 379-384.

CABALLERO R., GOICOECHEA E.L., HERNAIZ P.J. (1995): Forage yields and quality of common vetch and oat sown at varying seeding ratios and seeding rates of common vetch. Field Crops Res., 41, 135-140.

CABALlERO R., ALZUETA C., ORTIZ L.T., RODRIQUE M.L., BARO C., REBOLE A. (2001): Carbohydrate and protein fractions of fresh and dried common vetch at three maturity stages. Agronomy Journal, 93, 1006-1013.

CASTRO M.P., PINEIRO J., SAU F. (2000): Effect of seeding rates of oats, wheat and common vetch on the yield, botanic composition and nutritive value of the mixture, In: Sulas L, editor, Legumes for Mediterranean forage crops, pastures and alternative uses, Zaragoza: CIHEAM-IAMZ, 2000, 207-211.

DUNHAM J.R. (1998): Relative feed value measures forage quality, Forage Facts 41, KState AES and CES, pp 3.

GOERING H.K., VAN SOEST P. J. (1970): Forage fiber analysis, In: Agricultural handbook, No. 37. USDA, Washington, DC. 
GULCAN H., SAGLAMTIMUR T., ANLARSAL A.E., TANSI V. (1988): Research on hay yield of different vetch + oat mixture ratios and seeding times under Cukurova conditions, Agricultural Faculty of Cukurova University Publish, Adana, 3, 108-118.

HACKMANN T.J., SAMPSON J.D., SPAIN J.N. (2008): Comparing relative feed value with degradation parameters of grass and legume forages, J Anim Sci, 86, 2344-2356.

HADJICHRISTODOULOU A. (1978): Genotype, environment and rainfall effects on common vetch varieties in a semiarid region, Exp. Agric., 14, 81-87.

KARADAG Y., BUYUKBURC U. (2003): Effects of seed rates on forage production, seed yield and hay quality of annual legume-barley mixtures, Turk. J. Agric. For., 27, 169-174.

KARAGIĆ Đ., KATIĆ S., MIHAILOVIĆ V., VASILJEVIĆ S., MIKIĆ A., MILIĆ D. (2008): What a seed producer need from a plant breeder, Abstracts of the Second Grain Legumes Technology Transfer Platform (GL-TTP) Workshop, Novi Sad-Serbia, 27-28 November, 56.

KOKTEN K., TOKLU F., ATIS I., HATIPOGLU R. (2009): Effects of seeding rate of forage yield and quality of Vetch (Vicia sativa L.) - Triticale (Triticosecale Wittm.) mixtures under East Mediterranean rainfed conditions. African Journal of Biotechnology, 8, 20, 5367-5372.

LITHOURGIDIS A.S., VASILAKOGLOU I.B., DHIMA K.V., DORDAS C.A., YIAKOULAKI M.D. (2006): Forage yield and quality of common vetch mixtures with oat and triticale in two seeding ratios, Field Crops Research, 99, 106-113.

MIHAILOVIĆ V., MIKIĆ A., KATIĆ S., VASILJEVIĆ S., PATAKI I., MILIĆ D., KARAGIĆ Đ. (2008): Future challenges in breeding annual forage legumes in the Institute of Field and Vegetable Crops in Novi Sad, Serbia. Proceedings of the International Conference Conventional and Molecular Breeding of Field and Vegetable Crops, Novi Sad, Serbia, 24-27 November 2008, 438-442.

MIHAILOVIĆ V., MIKIĆ A., MATIĆ R., ĆUPINA B., KATIĆ S., KARAGIĆ Đ., ERIĆ P., KRSTIĆ Đ. (2007): A comparative study on the forage yield in winter and spring cultivars of pea (Pisum sativum L.) and common vetch (Vicia sativa L.). Proceedings of the COST Action 852 Final Meeting Quality Legume-Based Forage Systems for Contrasting Environments, Gumpenstein, Austria, 30 August - 3 September 2006, 193-195.

MIŠKOVIĆ B. (1986): Krmno bilje, Naučna knjiga, Beograd, 323 p.

MSTAT-C (1988): A Microcomputer Program for Design, Management, and Analysis of Agronomic Research Experiments, Crop and Soil Sciences Department, Michigan State University, East Lansing.

OSMAN A.E., NERSOYAN N. (1986): Effect of the proportion of species on the yield and quality of forage mixtures, and on the yield of barley in the following year. Exp. Agric., 22, 345-351.

REBOLE A., ALZUETA C., ORTIZ L.T., BARRO C., RODRIGUEZ M.L., 
CABALLERO R. (2004): Yields and chemical composition of different parts of the common vetch at flowering and at two seed filling stages, Spanish Journal of Agricultural Research, 2, 4, 550-557.

ROBERTS C.A., MOORE K.J., JOHNSON K.D. (1989): Forage quality and yield of wheat-common vetch at different stages of maturity and common vetch seeding rate. Agronomy Journal, 81, 57-60.

ROBINSON R.C. (1969): Annual legume: cereal mixtures for forage and seed, Agronomy Journal, 61, 759-761.

SEVEN P.T., CERCI I.H. (2006): The effects on nutrient digestibility of hay and silages made in different conditions in lambs, Veterinarski arhiv, 76, 2, 111-117.

SIEFERS M.K., BOLSEN K.K. (1997): Agronomic and silage quality traits of winter cereals. XVIII International Grassland Congress, June 8-19, Canada, 17, 9192.

THOMPSON D.J., STOUT D.G., MOORE T. (1992): Forage production by four annual cropping sequences emphasizing barley irrigation in southern interior British Columbia, Can. J. Plant Sci., 72, 181-185.

TUKEL T., HASAR E., HATIPOGLU R. (1997): Effect of mixture rates and cutting dates on the forage yield and quality of vetch-triticale mixtures and their seed yields under lowland conditions of Cukurova. XVIII International Grassland Congress, June 8-19, Canada, 25-26.

TUNA C., ORAK A. (2007): The role of intercropping on yield potential of common vetch (Vicia sativa L.)/oat (Avena sativa L.) cultivated in pure stand and mixtures, Journal of Agricultural and Biological Science, 2, 2, 14-19. 